\title{
委員会報告
}

\section{胃ファントム班報 告}

\author{
撮影技術委員会・委員長 岡 村 裕之 \\ 胃ファントム班・班長林 太 郎 \\ 班員 熊谷和正・坂下邦雄・酒井尚信 \\ 佐 藤 律·男·永井義 衛
}

\section{1. はじめに}

胃ファントムについては幾多の研究発表やファントム 專門委員会 ${ }^{122}$ の報告がある.

胃ファントム研究班結成の動機は，昭和52年撮影技術 専門委員会遠藤委員が現在の胃ファントムについてアン ケート調查を行った結果, 幾多の問題点が指摘されたの で, との問題を解決すべく佐々木委員長の命で昭和 52 年 11月胃ファントム研究班を学会干葉支部で結成発足した. そして JIS 規格ファントムでは困難な圧迫，ファントム 内胃本体の交換, 更には体内線量分布の測定も可能な, いわゆる万能型胃ファントムの完成を目標に放射線医学 総合研究所を Key station として製作を開始した.

\section{1 胃用ファントムについてのアンケート} 回答施設数: 27

I . 消化器検査使用中のX線設置

a . 暗室透視形

1台：7，2台：4，3台：5，4台：3

b. X-TV 形

1台：2, 2 台：4, 3 台：6, 4 台：3, 5 台：1，6台：1，7台：3

II. ファントムの使用について 使用中：15，不使用：10

III. 使用中のファントムの形態

1. JIS 形: 8

2. 胃の模形型： 7

3. 線チャート(十)バーガーファントム形: 4

4. その他： 4

IV. 使用目的

1. 装置性能(画質)のチェック：12

2. 研究用: 10
3. 日常管理：11

4. その他：1（カセッテ，スクリーンのテスト）

$\mathrm{V}$. 満足度

1. 満足： 4

2. 不満足：12（やや満足：2）

VI. 不満足の原因

1. 生体之不一致: 4

2. 腹部の吸収濃度がでない

3. 形状の 2 と 3 項の組合せが必要： 2

4. 胃粘膜

5. 照射線量測定

VII. ファントムに対する意見

1. 線チャート，アクリルファントム 線量計で代用している。

2. 立位可能形がほしい。

3. JIS 形は人体とくらべて卧位時では厚さが大.

4. JIS 形でもよいが，内側仿胃形のフォントムを 入れられるようにしたもの。

5. 合成樹脂製でよいすのを.

6. 静止, 動態の両方が測定できるように.

7. 胃の体形々交換できるむの.

8. 統一したすのがほしい.

\section{2 アンヶートの整理}

アンケート項目 V, VI, VIIを解決すべく, 先づ胃つァ ントムの使用目的について分類を行い，現在市販されて いるファントムを改良すべく使用目的個々について検討 した. その問題点を次に挙げる.

\subsection{1 胃の撮影条件を求めるとき}

A. 自動制御を行う際は検出部のチェックアップ.

B. 短時間撮影を行う際は撮影条件の決定.

人体の場合は，被写体が同じでも体型や年略，更には 
体位により透過X線量に差を生じるが, ファントムの場 合は立位，臥位とも厚さが変らないので，臨床に即した 人体等価撮影条件を求为難い.

\subsection{2 胃粘膜検の影出能を調べるとき}

人体の場合は, 立位, 臥位 (背, 腹) で form や falte の現れ方が異るのに対しフファンムでは単純な form や falte の影出にとどまる。

\subsection{3 胃の圧迫撮影と胃内空気量の調整}

人体においては腹部に弾力性があることから胃の圧迫 撮影や胃内空気量の調整は容易であるが，ファントムの 場合は空気量の調整や庄迫撮影は困難である。

\subsection{4 体内線量, 側方散乱線量の測定}

市販の固体ファントムでは，体内任意点の線量の計測 は難しい．単に側方散乱線だけを測定するのであれば， 高価な胃ファントムを用いなくてむっアアクライトや Mix DP の上うな組織等価物質で代用することができ る.

1.2.5 施設内にある関係した装置の管理，ならびに 施設間の装置，撮影条件を比較するとき

\subsection{6 撮影技術の実習（学生実習）}

\subsection{7. 廉価で大量生産が可能なこと}

ファントム班は以上各項を満足させるべく，人体近似 胃万能ファントムの完成を目標に製作を開始し， 3 年の 歳月を経て昭和56年 3 月完成をみたのでその全貌を報告 する。

\section{2. ファントム仕様}

Table 1 亿示す本仕様によるファントムは, 本研究班

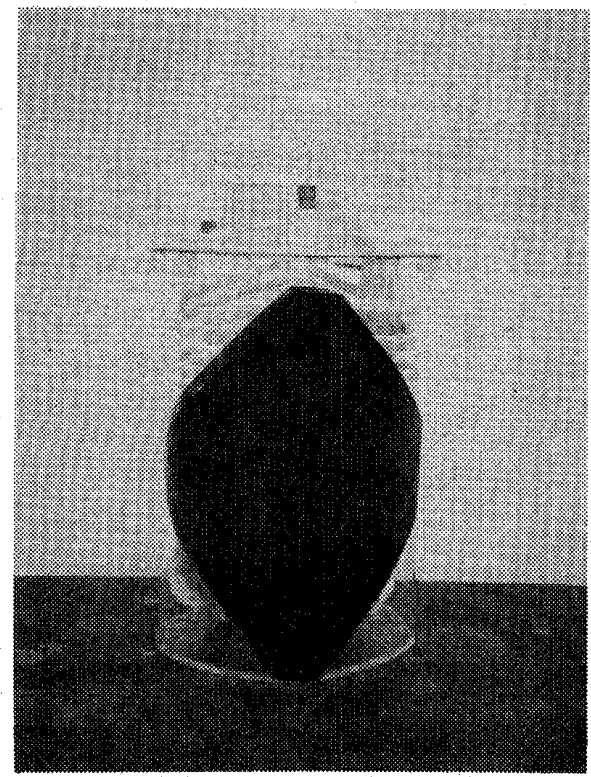

Fig. 1 a 正面
においては，2号型となるが（Fig. 1 a, b c c)，乙れを， 本体部，骨部，胃部に分けて，1 号型及び基礎実験用に

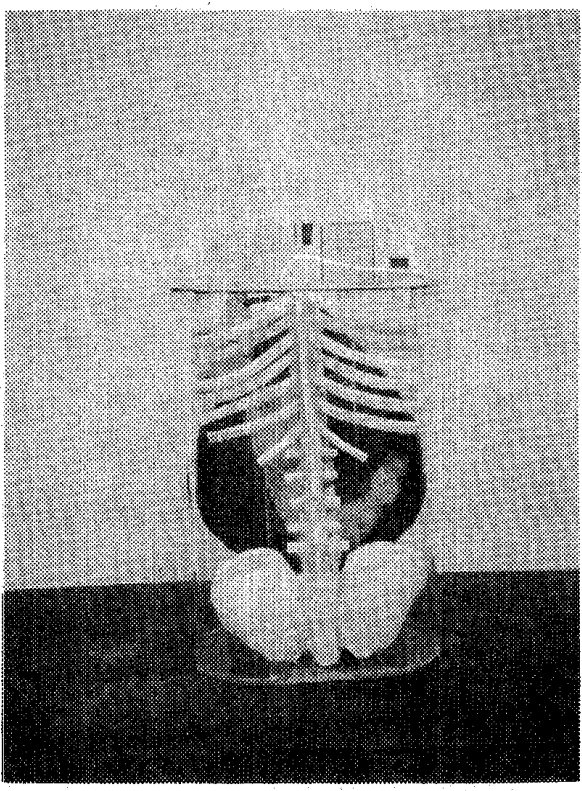

Fig. 1 b 背面

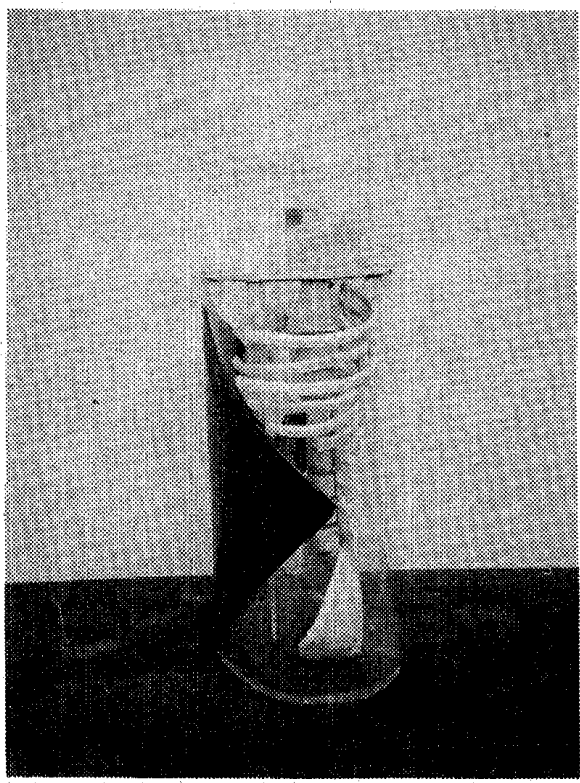

Fig. $1 \mathrm{c}$ 側面

Table 1 П型ファントムの仕様

\begin{tabular}{cl}
\hline \hline 重量 & $22 \mathrm{~kg}$ \\
" & $6.5 \mathrm{~kg}$ (内部の水無し) \\
高さ & $55 \mathrm{~cm}$ \\
$\prime$ & $44 \mathrm{~cm}$ (コントロール部の付属品を除く) \\
幅 & $28.5 \mathrm{~cm}$ \\
厭さ & $20 \mathrm{~cm}$ (立 位) \\
& $19 \mathrm{~cm}$ (仰臥位) \\
& $20 \mathrm{~cm}$ (腹臥位) \\
\hline
\end{tabular}




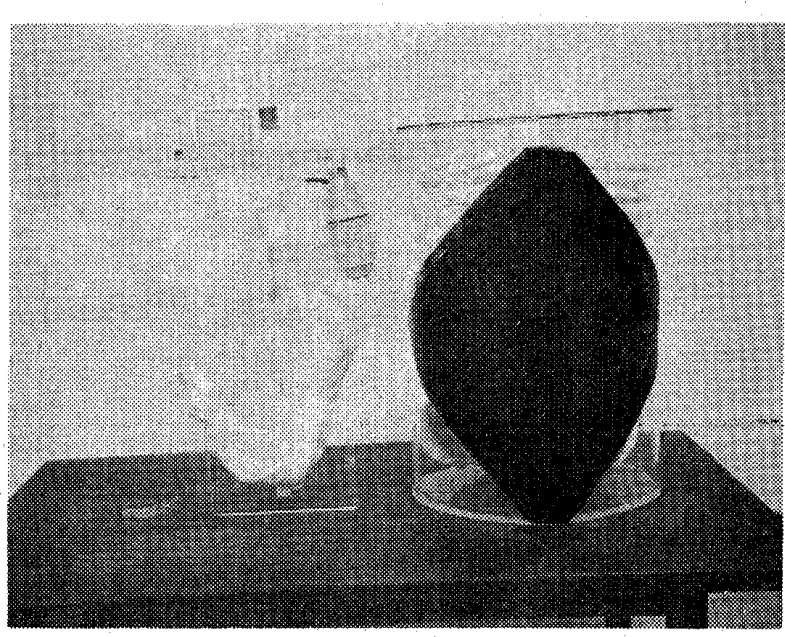

Fig. 2 ファントムとその队部

木製陚作したファントムから得たデータ等を含めて解説 する.

\section{1 本体部}

体位による腹厚の変化が可能なこと，王迫が可能なと と，等の条件により，ファントム内には液体を潂たし， 腹壁に当たる部分には組織等俩のゴムを使用した。 又，

Fig. 2 のごとく, 内部の胃部, 水中ポンプとそのコント ロール系統等は, ファントム内からそっくり取り出すと とが可能にしてある.

\section{1 .1 体位による腹厚の 変化}

標準人の場合，立位と仰卧 位との腹厚の差は $1.5 \sim 2.5$ $\mathrm{cm}$ である。この值を淦是さ せるのに，腹壁に相当する部 分を厚さ $12 \mathrm{~mm}$ の Mix-R （組織等価ゴム）を使用した。

Fig. 3. a は立位の模式であ りファントム内化たされ た水の水庄により腹愿は厚く なる、また，Fig. $3 \mathrm{~b}$ は仰卧 位の様式であり，ファントム 上部に取りつけたゴム袋にフ ァントム内の水が流れ込むと

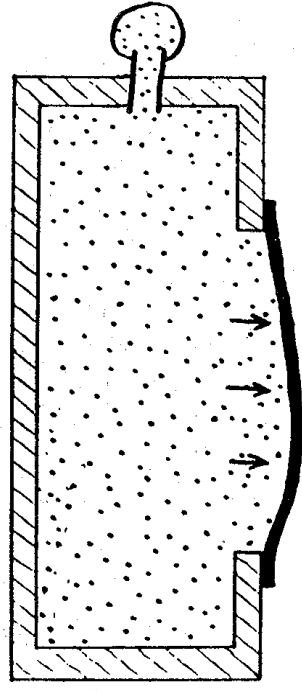

Fig. $3 a$ 立位

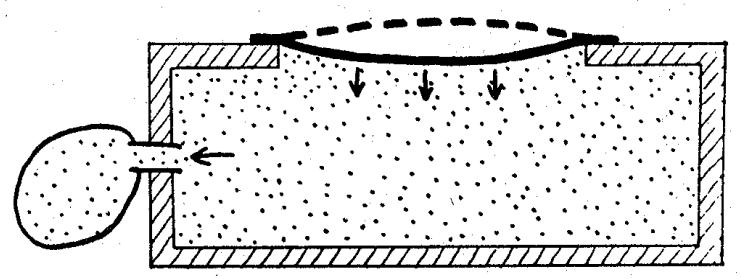

Fig. 3 b 仰臥位
とにより，腹厚を減じるととが可能となる。

\section{1 .2 圧迫について}

腹壁を弾力性のある組絨等価ゴムにしたため，原則的 には，圧迫を可能にしたと言えるが実際には，立位で压 迫する場合，球迫により減ずる体績分の水をコントロー ルのゴム袋（Fig. 1 では，ファントム上部の大きな方の 箱の部分）まで押し上げるに足るエネルギーが必要であ り，現在の遠隔操作型のディスティンクトール（压迫力 は $9 \mathrm{~kg}$ 前後)、では不充分であり，尼迫の效果はほとん ど無い.との解決策として水中ポンプを用いて，压迫時 のみファントム内の水を汲み上げる方法をとった（Fig. 2 ではゴム袋部の下方に芫えるのが水中ポンプ）モータ の作動センサとコントロール系を Fig. 4 亿示す.また， 腹壁ゴム内面に, 深さ $2 \mathrm{~mm}$ の切れ目を $5 \mathrm{~mm}$ 角のメッ シュとして刻み，ゴムの弾力そのものによる押しもどし 力を弱めてある.

\section{2 骨部}

市販のマーゲンファントムの中には，人骨を入れたす のがあるが，規格性亡，価格面から，骨等洒物質を製作 した，原材料は，安定性（水中に放置する時間が長いの で, 主として水溶性), 価格を考慮し，ポリエチレンをべ 一スにして，炭酸石灰とリン酸一水素カルシウムを 110 ${ }^{\circ} \mathrm{C}$ てて混煉した。

学等価物質組成（カッコ内はICRU）

\begin{tabular}{|c|c|c|}
\hline 素 & $8 \%$ & $(6.0 \%)$ \\
\hline 素 & $48 \%$ & $(28,0 \%)$ \\
\hline 素 & - & $(3.0 \%)$ \\
\hline 素 & $22 \%$ & $(41.0 \%)$ \\
\hline マグネシウム & - & $(0.2 \%)$ \\
\hline ン & $8 \%$ & $(7.0 \%)$ \\
\hline 黄 & - & $(0.2 \%)$ \\
\hline カルシウム & $15 \%$ & $(15.0 \%)$ \\
\hline 度 & 1. 24 & $(1.86)$ \\
\hline 効原子番号 & 11.53 & (11.6) \\
\hline
\end{tabular}

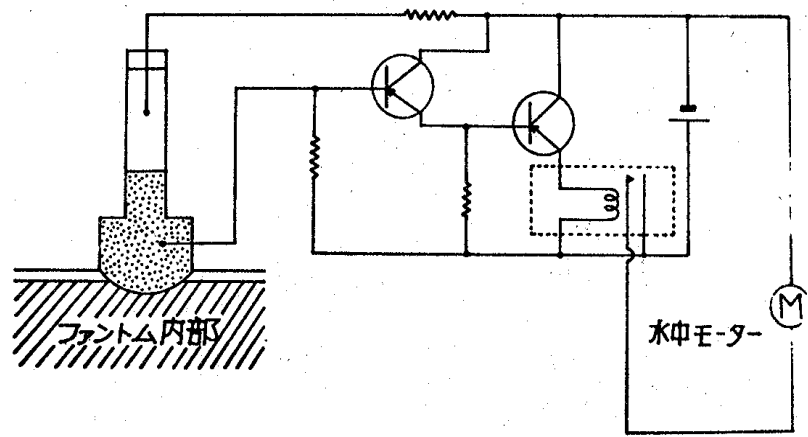

Fig. 4. 


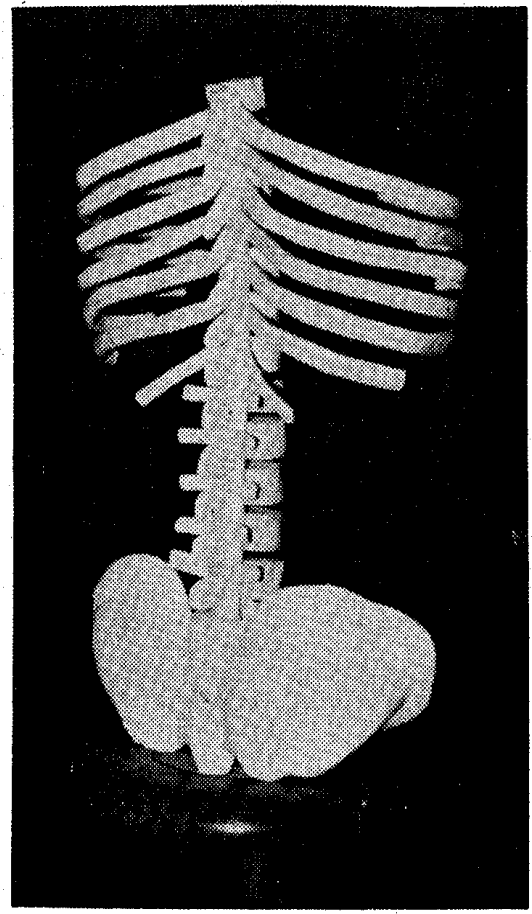

Fig. 5

電子密度

3. $24 \times 10^{23}\left(3.19 \times 10^{23}\right)$

Fig. 5 及び Fig. 6 a, b 亿，製作骨の外観と，そのう ジオグラフィーを示す.

\section{3 胃部}

圧迫の可能性，二重造影ができる，等の条件が必要な ため, 必然的に，ゴム袋状となった。形状等は別として， 材質的に二種類の胃を製作した。一つは，天然ラテック スの薄膜に，生ゴム液を塗布し，青小区風なパターンを 生じせしめたもの.あう一つは，ゴムスポンジを形に入 れて，すう壁の部分む一緒に成形したものである，ての スポンジ法によるあのは，材質中にかなりの空気の混大

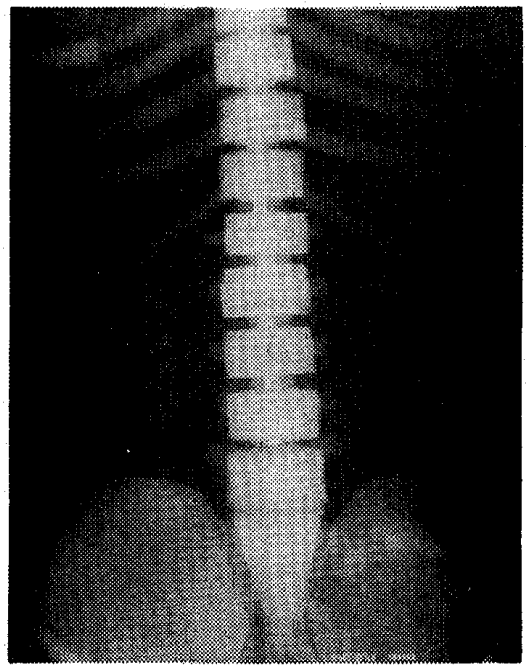

Fig. 6 a

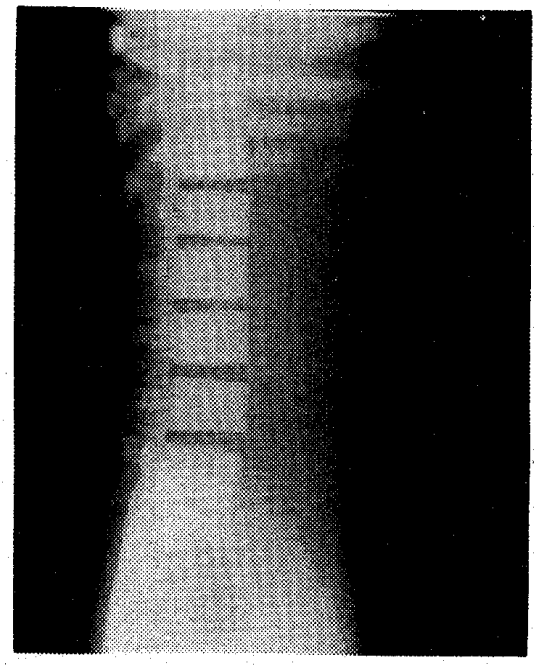

Fig. $6 \mathrm{~b}$

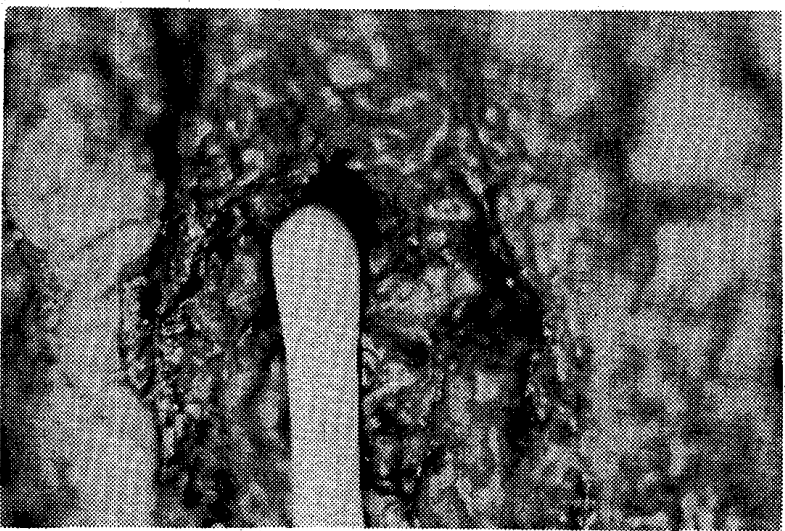

Fig. 7 a 溥膜法による胃の内面(比較は マッチ捧)

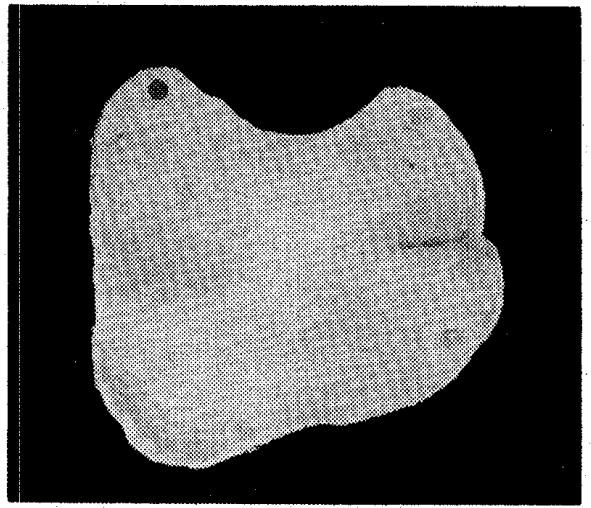

Fig. 7 b スポンジ法による内面

があるため，密度が低下する。乙れを補なう意味で，実 効原子番号の高いシリコンゴムを素材亡した. 又, スポ ンジに造影剂及び我の浸み込みを防止するために，表面 にはラテックスのコーティングをほどこした.

Fig. 7 a, bは，薄膜法尤り製作したもの之，スポン ジ法により製作したものの内面を示し，てれらの比較を 
Table 2

\begin{tabular}{|c|c|c|}
\hline & 膜 & スポン シ 法 \\
\hline 製作の難易 & 難 & 易 \\
\hline 組織等価性 & 良 & $\begin{array}{l}\text { スポンジ状のため, ラテックスコー } \\
\text { 卜はあるもの, 多少の贪水性があ } \\
\text { り，その程度により不安足 }\end{array}$ \\
\hline バリウムの乗り & & 良 。 \\
\hline ファントム中でのつぶれ & $\begin{array}{l}\text { 水压により,ぼぼ完全につぶれるた } \\
\text { めガスの残留はほとんどない. }\end{array}$ & $\begin{array}{l}\text { 胃壁が厚い }(2 \sim 4 \mathrm{~mm}) \text { のため, 単 } \\
\text { 純撮影でのガス残留が気になる. }\end{array}$ \\
\hline 柔軟性, 伸縮性 & $\begin{array}{l}\text { 良‥強制的に曲げた場合, 連続的に } \\
\text { 曲がる. }\end{array}$ & $\begin{array}{l}\text { 難……連続的に曲がらないる } \\
\text { (一カ所で折れた状態となる) }\end{array}$ \\
\hline 質 感 & & 良 \\
\hline 物理的性質 & $\begin{array}{l}\text { 品湿性があり, やや膨脹する. 引張 } \\
\text { りに強い. }\end{array}$ & $\begin{array}{l}\text { 吸湿性なし.含水性は大. } \\
\text { 所的な引張りに弱い。 }\end{array}$ \\
\hline 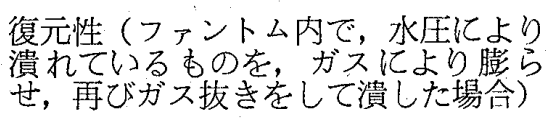 & やや不良 & 良 \\
\hline ファントム内への固定 & 難 & やや易 \\
\hline 規格性 & やや難 & 比較的易 \\
\hline 経済性 & やや難 & 良 \\
\hline
\end{tabular}

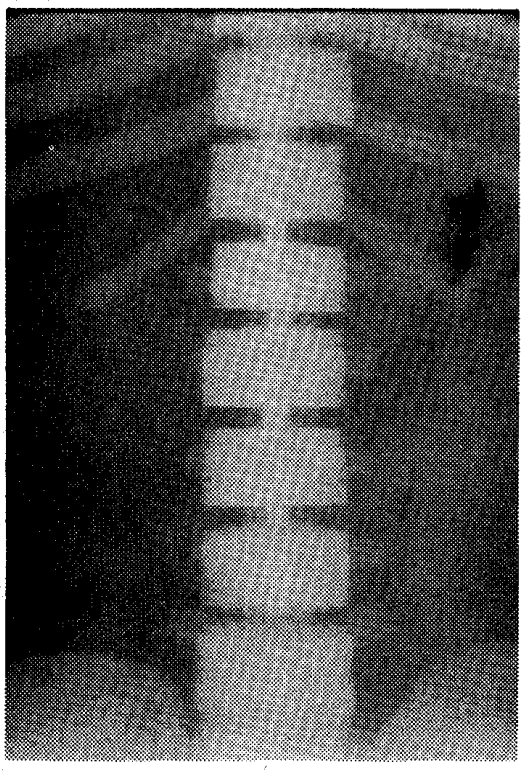

Fig. 8a 薄膜法による

Table 2 亿挙げる. 又, 胃のファントム内での, 固定は, 噴閒部，幽門部，大筿僛の3 点で行った。

\section{3. 総 合 結 果}

前節での，本体，骨，胃の各部を合体したものについ て, Fig. 8 a,bに，その単純写真を示すが胃部の比較 (Table 2) にある様に，スポンジ法のそれの残気留がや や気になる. バリウムを約 $150 \mathrm{ml}$ 流し込んだあのが Fig. 9 a b bであり，Fig. 9bに発泡戍を使用したすのが Fig. 10 (スポンジ法によるもの) である. 又, Fig. 11

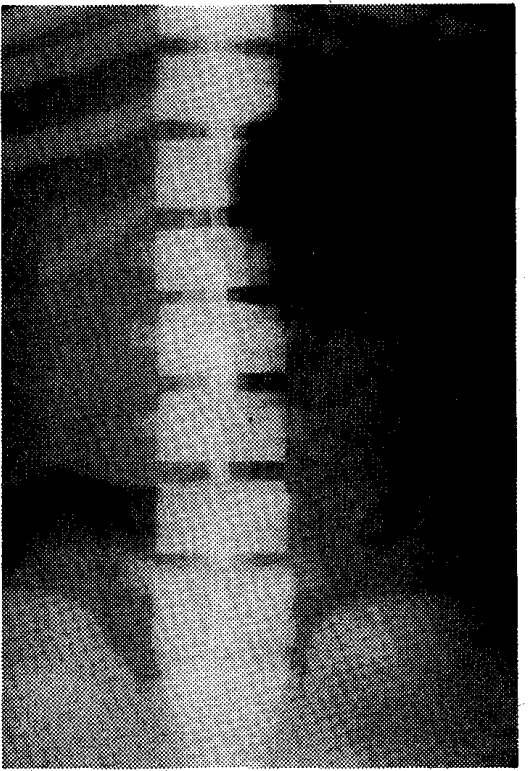

Fig. 8 b スポンジ法による

に，薄膜法による6のに $250 \mathrm{ml}$ のバリウムを入れたも のを示す. 最後にディスティンクトールにより庄迫した ものを Fig. 12 a, b 亿示9. 尚との場合の胃は, スポン ジ法による6のであり，内壁にポリープ状の突起を作っ たものである。

\section{4.おわりに}

3 年強に宣たる本研究す, 公開討諭会時に毎々とり上 げてきた圧迫時の水圧の問題と, その他物理的な諸問題 解決にほとんどの時間を費やしてしまい，胃の固定等の 


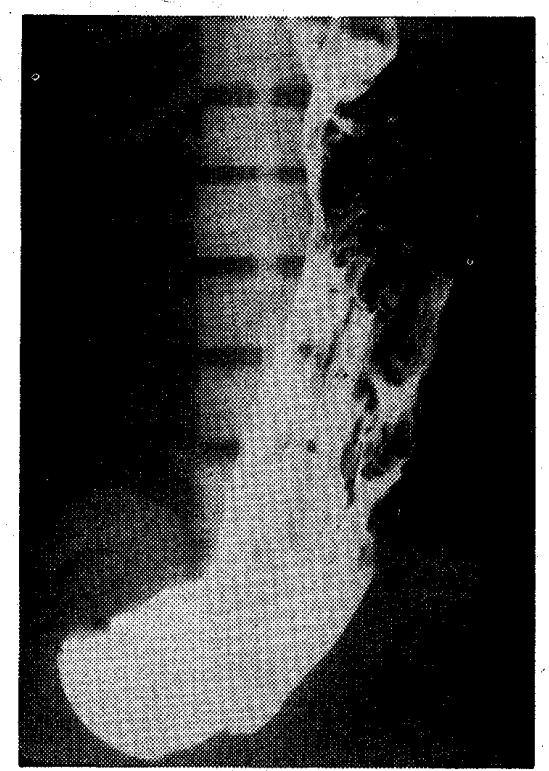

Fig. 9a 薄膜法による

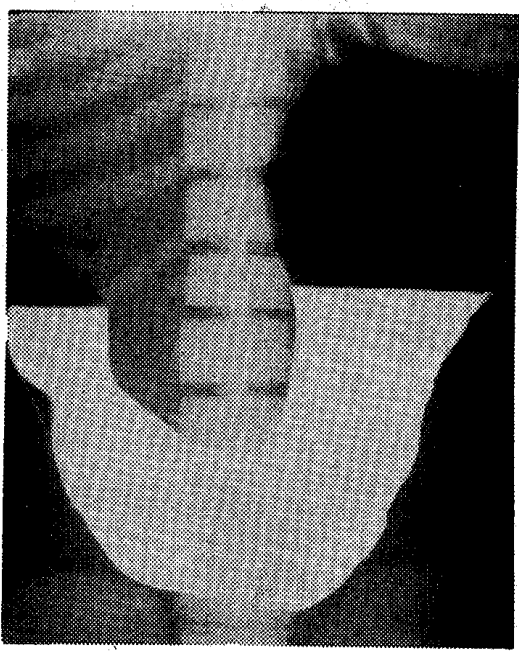

Fig. 10

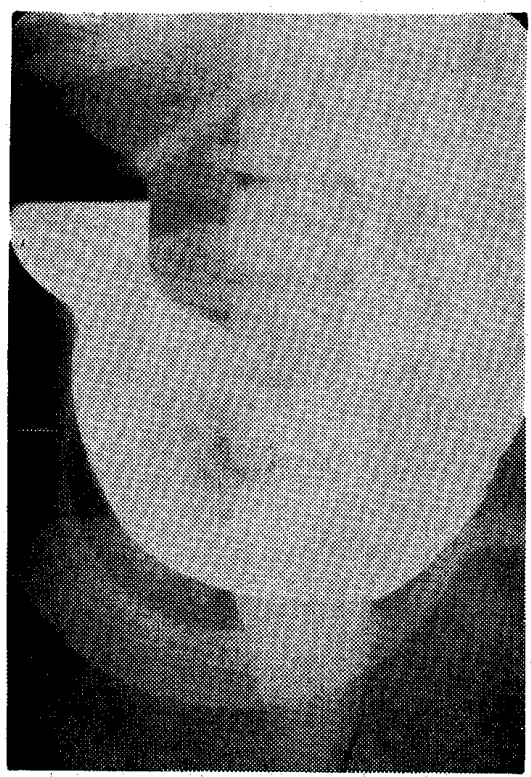

Fig. 12a

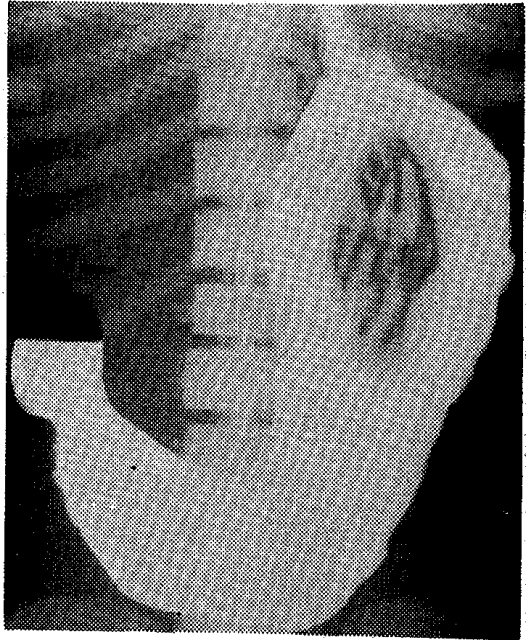

Fig. 9b スポンジ法

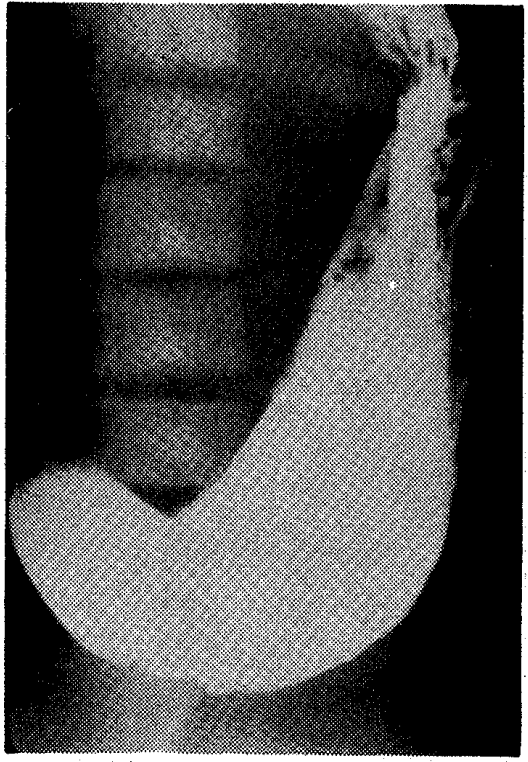

Fig. 11

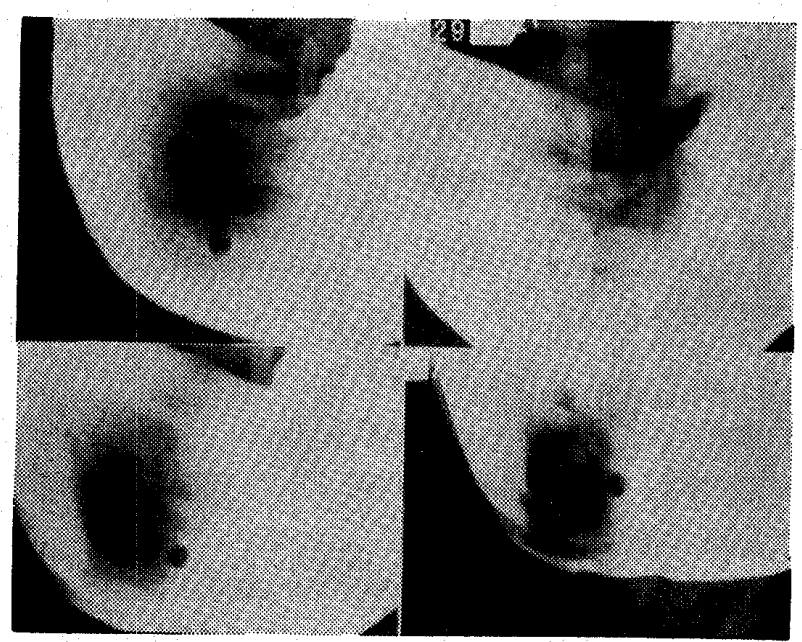

Fig. 12 b 
問題は，大部分残存したままであり，所期の目的を達し たとは言い難く，研究班としては心苦しい次第である. しかし，圧迫の問題は，大筋での解決を見ており，又， 撮影用の骨等価物質の試作等, ての $1 \sim 2$ 年, 総会で本 研究に類似した研究が見られる昨今, 是非参考にしてい ただきたいと考えます。

尚， 几型ファントムは, 学会事務局に常置しておきま す.

報告を終るにあたり，胃本体の製作に多大の御援助を
賜った鬼怒川ゴム(株)研究室の研究員の皆様に束心より 感謝する。

\section{文献}

1）增野 豊, 岡野健吾, 他: 胃ファントム, 日放技学 誌, 23(5), 373-382.

2）中村 実: ファントム専門委員会報告. 日放技学誌, 23(4), 339-363. 